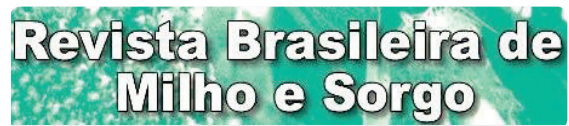

Brazilian Journal of Maize and Sorghum

ISSN 1980 - 6477

Journal homepage: www.abms.org.br/site/paginas

Ênio Gomes Flôr Souza ${ }^{(1)}(\bowtie)$, Denisson Lima do Nascimento $^{(1)}$, Raquel Soares da Silva ${ }^{(1)}$, Thiago Pereira da Silva ${ }^{(1)}$, Dalbert de Freitas Pereira ${ }^{(1)}$ Juliana Souza Barros ${ }^{(2)}$, Ellen Abreu da Cruz ${ }^{(1)}$ and Michelangelo de Oliveira Silva

Instituto Federal de Alagoas, Campus Piranhas E-mail: enio.souza@ifal.edu.br

denisso2011_@hotmail.com

raquel.ssm16@hotmail.com

thiagopdseng@gmail.com

dalbert.freitas@gmail.com

ellen.cruz@ifal.edu.br

michelangelo.silva@ifal.edu.br

(2) Universidade Federal de Sergipe

E-mail: juliana.barrosx@outlook.com

Corresponding author

How to cite

SOUZA, Ê. G. F.; NASCIMENTO, D. L.; SILVA,

R. S.; SILVA, T. P.; PEREIRA, D. F.; BARROS

J. S.; CRUZ, E. A.; SILVA, M. O. Leaf diagnosis and productivity of forage sorghum fertigated with nitrogen doses in two harvests. Revista Brasileira de Milho e Sorgo, v. 20, e1201, 2021.

\section{LEAF DIAGNOSIS AND PRODUCTIVITY OF FORAGE SORGHUM FERTIGATED WITH NITROGEN DOSES IN TWO HARVESTS}

\begin{abstract}
The aim of the present study was to evaluate the degrees of macronutrients in the diagnostic leaf and the productivity of forage sorghum IPA 467 , submitted to fertigation with nitrogen doses, during two harvests (summer and winter), both without regrowth. From January 20 to May 18 and from June 17 and October 14, 2016, two experiments were conducted in Canindé de São Francisco, State of Sergipe, in the Brazilian semi-arid. The experimental design was randomized complete blocks, with four replications. The treatments consisted of four doses of $\mathrm{N}\left(0 ; 80 ; 160\right.$ and $\left.240 \mathrm{~kg} \mathrm{ha}^{-1}\right)$. Joint analysis of variance was carried out, considering each different harvest as a new factor. The characteristics evaluated were the content of nitrogen $(\mathrm{N})$, phosphorus $(\mathrm{P})$, potassium $(\mathrm{K})$, calcium $(\mathrm{Ca})$ and magnesium $(\mathrm{Mg})$ in the leaves, height of the plant, diameter of the stem,green mass productivity, dry mass productivity and percentage of dry mass. The macronutrient content in the leaves was incremented with increasing doses of $\mathrm{N}$, except $\mathrm{Ca}$ which presented no influence. The winter crop promoted the highest content of $\mathrm{K}$, while the summer crop presented an elevated absorption of $\mathrm{Mg}$. The varying dosage of $\mathrm{N}$ or the harvests season did not influence dry mass productivity (average of 17,386 ton/ $\left./ \mathrm{ha}^{-1}\right)$. The content of $\mathrm{N}\left(23.16-26.68 \mathrm{~g} \mathrm{~kg}^{-1}\right)$, $\mathrm{P}\left(3.16-4.11 \mathrm{~g} \mathrm{~kg}^{-1}\right), \mathrm{K}\left(10.98-33.36 \mathrm{~g} \mathrm{~kg}^{-1}\right), \mathrm{Ca}\left(3.61 \mathrm{~g} \mathrm{~kg}^{-1}\right)$ and $\mathrm{Mg}(4.78-9.64 \mathrm{~g}$ $\mathrm{kg}^{-1}$ ) can be considered enough for the full development of the plant.
\end{abstract}

Keywords: Sorghum bicolor, application of fertilizer, mineral nutrition.

\section{DIAGNOSE FOLIAR E PRODUTIVIDADE DE SORGO FORRAGEIRO FERTIRRIGADO COM DOSES DE NITROGÊNIO EM DUAS SAFRAS}

Resumo - Objetivou-se avaliar os teores de macronutrientes na folha diagnóstica e a produtividade do sorgo forrageiro IPA 467 fertirrigado com doses de nitrogênio (N) em duas safras (verão e inverno), ambas sem rebrota. Nos períodos de 20 de janeiro a 18 de maio e de 17 de junho a 14 de outubro de 2016, foram conduzidos dois experimentos em Canindé de São Francisco, Semiárido de Sergipe. O delineamento experimental foi em blocos ao acaso, com quatro repetições, e os tratamentos consistiram em quatro doses de N $\left(0 ; 80 ; 160\right.$ e $\left.240 \mathrm{~kg} \mathrm{ha}^{-1}\right)$. Realizouse análise conjunta de variância, considerando as safras como novo fator. As características avaliadas foram os teores foliares de $\mathrm{N}$, fósforo $(\mathrm{P})$, potássio $(\mathrm{K})$, cálcio $(\mathrm{Ca})$, magnésio $(\mathrm{Mg})$, altura de planta, diâmetro de colmo, produtividades de massas verde e seca, e porcentagem de massa seca. Os teores foliares de macronutrientes foram incrementados com as doses crescentes de $\mathrm{N}$, com exceção do Ca que não foi influenciado. A safra de inverno promoveu maior teor de $\mathrm{K}$, enquanto a de verão foi mais benéfica para absorção de $\mathrm{Mg}$. As doses de $\mathrm{N}$ e as safras não influenciaram a produtividade de massa seca da cultura (média de 17.386 ton/ha' $\left.{ }^{-1}\right)$. Os teores de $\mathrm{N}\left(23,16-26,68 \mathrm{~g} \mathrm{~kg}^{-1}\right), \mathrm{P}\left(3,16-4,11 \mathrm{~g} \mathrm{~kg}^{-1}\right), \mathrm{K}(10,98-33,36$ $\left.\mathrm{g} \mathrm{kg}^{-1}\right), \mathrm{Ca}\left(3,61 \mathrm{~g} \mathrm{~kg}^{-1}\right)$ e $\mathrm{Mg}\left(4,78-9,64 \mathrm{~g} \mathrm{~kg}^{-1}\right)$ podem ser considerados suficientes para o pleno desenvolvimento da cultura.

Palavras-chave: Sorghum bicolor, aplicação de fertilizante, nutrição mineral. 
Sorghum (Sorghum bicolor L.) stands out as a specie of great importance for animal nutrition in the semiarid regions of Brazil. As a plant with immense fodder performance, regrowth capacity and adaptability in dry climates, making sorghum capable of surviving and becoming productive under limited supply conditions (Elias et al., 2016). Because of these characteristics, it is used in numerous products, for grain silage, green cut, animal grazing, and grain, in animal feeds and for human consumption (Buso et al., 2011).

In the Brazilian semiarid, this species has been cultivated both in rainfed condition and under irrigation. Despite its higher tolerance for water deficits when compared to corn, sorghum, does present a negatively affected productivity whenever it is cultivated in semiarid conditions without irrigation due to erratic pluviometric fluctuations (Coelho et al., 2018). However, in irrigated areas the proper hydric regiment of the crop can be maintained throughout the cycle, enabling the use of fertilization techniques through the irrigation water (fertigation), which stands out as a way of applying fertilizers that mostly resembles the plants natural rate of water and nutrient absorption. Fertigated systems make for directly applying fertilizers in the densest root regions, allow for the fractioning of dosages and an increase in the efficiency of fertilization in order to increase production (Souza et al., 2020).

During its development, sorghum is a $\mathrm{N}$ demanding plant, this being a determining factor for the plants overall nutrition, its capacity of protein formation, assisting in photosynthesis, and augmenting its nutritional value and forage quality (Macedo et al., 2012). Due to this factor, $\mathrm{N}$ fertilization is an option for farmers that desire to increase its productivity. Nirmal et al. (2016) achieved linear increments of forage sorghum yields, up to doses of $310 \mathrm{~kg} \mathrm{ha}^{-1}$ of $\mathrm{N}$ reaching productions of 60.6 thousand $\mathrm{kg} \mathrm{ha}^{-1}$.

Furthermore, nitrogen fertilization for the cultivation of sorghum is a tried practice that can not only increase the absorption of this $\mathrm{N}$, but of other nutrients, like potassium $(\mathrm{K})$, phosphorus $(\mathrm{P})$, calcium $(\mathrm{Ca})$ and magnesium $(\mathrm{Mg})$ as well (Fonseca et al., 2008; Serrão et al., 2012). Accordingly, to know the macronutrient contents in sorghum leaves is essential for the management of nutrients, its absorption efficiency and for providing productivity gains and cost saving (Santos et al., 2014).

The macronutrient content in a diagnostic leaf of forage sorghum can increase with the use of increasing doses of $\mathrm{N}$ and stimulate an increase in biomass accumulation. This is the case especially when cultivated in winter weather conditions, in which the vegetative cycle is prolonged. In this context, the aim of this work was to evaluate the macro nutritional content $(\mathrm{N}$, $\mathrm{P}, \mathrm{K}, \mathrm{Ca}$ and $\mathrm{Mg}$ ) in the diagnostic leaf and the productivity of fertigated forage sorghum with varying $\mathrm{N}$ dosages during two different harvest seasons (summer and winter) in the Brazilian semiarid. 


\section{Material and Methods}

The experiment was conducted, at property located in Assentamento Valmir Mota, in the town of Canindé de São Francisco-SE,in the semiarid region of northeastern Brazil (9॰40'27'S, 3745'45'W, $194 \mathrm{~m}$ of altitude) and during two harvests, both excluding the evaluation of regrowth. The summer harvest was considered from January to April and winter, from June to October of 2016. The region's climate, according to the Köppen classification, is BSsh, hot, semiarid, steppe, with rainy season concentrate in April, May and June (Sousa et al., 2010). The average meteorological data during the experimental period was measured from an automatic meteorological station installed six kilometers away from the experiment's area (Figure 1).

The area's soil was classified as a Chromic Luvisol, with undulated topography and clayey - granulometric values of $478.20 \mathrm{~g} \mathrm{~kg}^{-1}$ of sand, $98.00 \mathrm{~g} \mathrm{~kg}^{-1}$ of silt and $423.80 \mathrm{~g} \mathrm{~kg}^{-1}$ of clay, with its chemical characteristics (Silva, 2009) described in Table 1.

The experimental design used was randomized complete blocks, with four replications. In both harvests, the treatments consisted of four doses of $\mathrm{N}(0 ; 80 ; 160$ and 240 $\left.\mathrm{kg} \mathrm{ha}^{-1}\right)$. These were parceled out, applying 15\% of the dosage at 15 days after emergence (DAE), $50 \%$ at $20 \mathrm{DAE}$ and $35 \%$ at $40 \mathrm{DAE}$, through a Venturi fertilizer injector. A dose of zinc $(2.0 \mathrm{~kg}$ $\left.\mathrm{ha}^{-1}\right)$ was applied by fertigation for all the samples, in the same proportion and time of application of $\mathrm{N}$. The doses of $\mathrm{N}$ and $\mathrm{Zn}$ were provided by urea and zinc sulphate fertilizers, respectively.

Each plot consisted of six rows with $6 \mathrm{~m}$ in length, spaced at $1 \mathrm{~m}$ apart, totaling an area of $36.0 \mathrm{~m}^{2}$ (6.0 rows x $\left.6.0 \mathrm{~m} \times 1.0 \mathrm{~m}\right)$. The four central rows, not including three plants in each end, were considered the usable area of the plot $\left(22.4 \mathrm{~m}^{2}=4\right.$ rows $\left.\times 5.6 \mathrm{~m} \times 1.0 \mathrm{~m}\right)$.
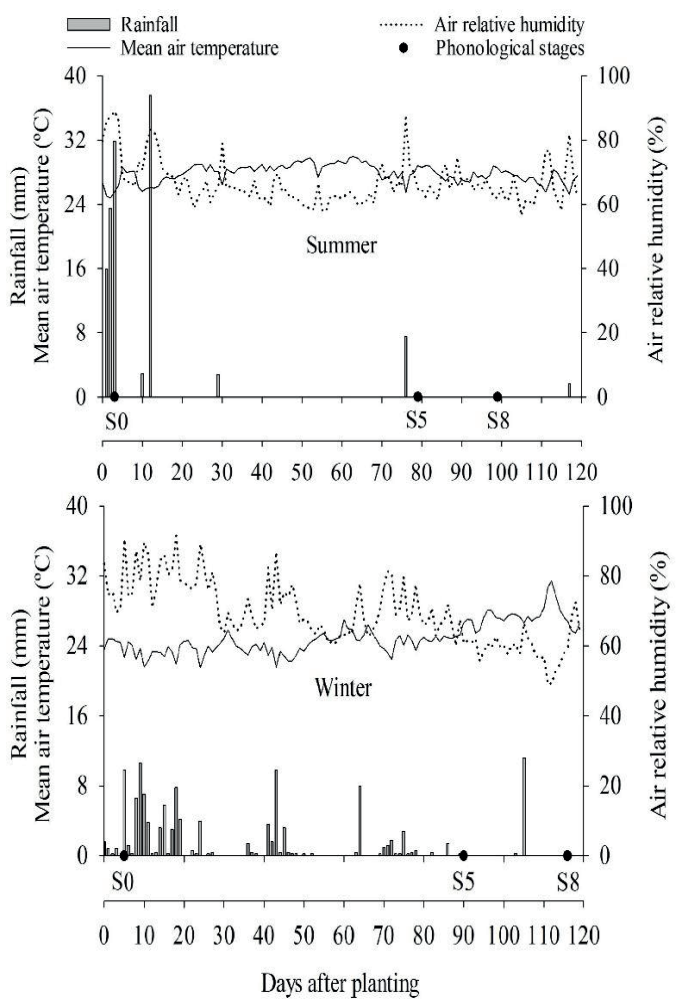

Figure 1 - Values of acumulated pluviometric precipitation, average air temperature, relative air humidity and indication of phenology stages (S0: emergence; S5: boot; S8: hard dough) of forage sorghum with nitrogen doses, in summer and winter harvests.

The soil preparation was accomplished 
Table 1 - Chemical soil analysis of experimental areas of forage sorghum (depth of 0 to $20 \mathrm{~cm}$ ), in summer and winter harvests.

\begin{tabular}{|c|c|c|c|c|c|c|c|}
\hline & $\mathrm{P}$ & $\mathrm{K}^{+}$ & $\mathrm{Ca}^{2+}$ & $\mathrm{Mg}^{2+}$ & $\mathrm{Na}^{+}$ & $\mathrm{Al}^{3+}$ & $\mathrm{H}+\mathrm{Al}$ \\
\hline Harvest & $\mathrm{mg} \mathrm{dm}-3$ & $---\cdot$ & ---1 & ---- & $\mathrm{dm}_{c}^{-3}$ & & \\
\hline Summer & 24.00 & 0.37 & 16.30 & 10.10 & 0.12 & 0.00 & 3.20 \\
\hline \multirow[t]{2}{*}{ Winter } & 26.00 & 0.43 & 18.60 & 8.20 & 0.27 & 0.00 & 0.00 \\
\hline & $\mathrm{pH}$ & $\mathrm{CE}^{1}$ & $\mathrm{MO}^{2}$ & $\mathrm{Cu}$ & $\mathrm{Fe}$ & $\mathrm{Mn}$ & $\mathrm{Zn}$ \\
\hline Harvest & $\mathrm{H}_{2} \mathrm{O}$ & $\mathrm{dS} \mathrm{m} \mathrm{m}^{-1}$ & $\mathrm{~g} \mathrm{~kg}^{-1}$ & \multicolumn{4}{|c|}{ - } \\
\hline Summer & 6.60 & 0.34 & 25.80 & 0.10 & 42.90 & 76.60 & 2.00 \\
\hline Winter & 7.10 & 0.57 & 34.70 & 0.60 & 41.80 & 103.00 & 2.50 \\
\hline
\end{tabular}

${ }^{1}$ EC: electrical conductivity. ${ }^{2} \mathrm{OM}$ : organic matter.

by two passes in a criss-cross pattern with a disk harrow, at an average depth of $20 \mathrm{~cm}$. Subsequently, parcels were demarcated and the sowed manually with forage sorghum IPA 467 in a spacing $1.0 \mathrm{~m} \times 0.2 \mathrm{~m}$ (three plants per hole, or 15 plants per meter, 150 thousand plants ha-1). The plantings were completed on January $20^{\text {th }}$, 2016 (summer) and June $6^{\text {th }}, 2016$ (winter) for each season. This variety presents as a strategic alternative when compared to other varieties due to the its adaptive potential in semi arid conditions and multivariate use for production of forage, silage and grazing.

The experiment had a drip irrigation system, with spacing of $0.2 \mathrm{~m}$ between emitters and an average flow of $1.2 \mathrm{~L} \mathrm{~h}^{-1}$, as the considered waterline obtained by the water balance of precipitation and evapotranspiration of the crop. The pluviometry precipitation accumulated 122 $\mathrm{mm}$ in summer and $113 \mathrm{~mm}$ in winter, while the gross irrigation depth totaled, $254 \mathrm{~mm}$ and $179 \mathrm{~mm}$ in summer and winter harvests, respectively. The crop management adopted during the experiment followed those used as standard by local producers in the region. The weed control was performed using the herbicide atrazina, applied in pre-emergence.

At 79 (summer) and 90 days after planting (winter), due to the booting of the grain, the second mature upper leaf was collected randomly in 10 plants of the usable area of each plot (Silva et al., 2008). Then, the dry mass of these leaves was measured after drying in a forced air circulation oven, with a set temperature of $65^{\circ} \mathrm{C}$, until it reached constant mass.

The leaves were ground in a Willey stainless steel cutting mill (Tecnal - TE-650), using a 2.0 $\mathrm{mm}$ mesh sieve. In order to determine the content of $\mathrm{N}\left(\mathrm{g} \mathrm{kg}^{-1}\right)$, the methodology described by Tedesco et al. (1995), was used. Measuring 200 mg of vegetal sample, and then transferring it to the digester tube, where $1 \mathrm{~mL}$ of $30 \%$ hydrogen 
peroxide and $3 \mathrm{~mL}$ of sulfuric acid were added. Subsequently, the mixture was introduced in a block digester at a temperature of 180 to $190{ }^{\circ} \mathrm{C}$ for two hours, followed by another hour at $350^{\circ} \mathrm{C}$.

To perform chemical analysis of the content of $\mathrm{P}, \mathrm{K}, \mathrm{Ca}$ and $\mathrm{Mg}$ the vegetal sample was put through a wet digestive process using microwave heating (CEM - Mars Xpress). For this, 200 $\mathrm{mg}$ of green mass were sampled and placed in perfluoroalkoxy ethylene (PFA) Teflon tubes, being digested with a mixture of $5 \mathrm{~mL}$ of nitric acid (70\%) and $3 \mathrm{~mL}$ of hydrogen peroxide (30\%). Posteriorly, the samples were measured with distilled water in a $25 \mathrm{~mL}$ volumetric flask.

Soon after, $\mathrm{P}$ was determined by colorimetry, in a wavelength of $725 \mathrm{~nm}$, while $\mathrm{K}$ was quantified by flame photometry, according to the methodology proposed by Silva (2009). The $\mathrm{Ca}$ and $\mathrm{Mg}$ were evaluated by Flame Atomic Absorption Spectrophotometry (Shimadzu - Varian AA-240).

The forage sorghum was harvested during its S8 phenology stage (hard dough grains), that corresponded to 99 (summer) and 111 (winter) days after planting. The diameter of the stem and the height of the plant were measured in 10 plants within the plot avaiable area. The diameter of the stem ( $\mathrm{mm}$ ) was measured at the first internode of the plant, approximately ten centimeters from the soil. The plant height $(\mathrm{cm})$ was considered between soil level and the insertion point of the highest leaf blade. The productivity of the sorghum in green mass $\left(\mathrm{kg} \mathrm{ha}^{-1}\right)$ was estimated from the green mass in the usable area of each plot. The productivity of the dry mass was estimated after drying of these plants in a forced air circulation oven, with temperature regulated to $65{ }^{\circ} \mathrm{C}$, until they reached constant mass. The percentage of dry mass (\%) consisted of the ratio between the measured productivities of dry mass and green mass.

For each agricultural harvest (summer and winter) the analysis of the variance of the plants characteristics were made using the software Silsvar, version 5.6 (Ferreira, 2011). After, a joint analysis was performed for those characteristics that presented homogeneity of variance between harvests. The regression equations for the dosages of $\mathrm{N}$ were selected based on the following criteria: biological explanation of the phenomenon, simplicity of the equation and testing the equation parameters by a Student $t$ test, at $5 \%$ probability. The averages of the harvests were compared by a Tukey test, at $5 \%$ probability.

\section{Results and Discussion}

The joint analysis of variance of the forage sorghum diagnostic leaf, macronutrient contents are presented in Table 2. For the variable referring to the content of $\mathrm{N}$, an isolated effect was observed depending on $\mathrm{N}$ dosage and harvests. In relation to the contents of $\mathrm{P}$ and $\mathrm{K}$, there was interaction among the $\mathrm{N}$ dosages and the harvests. Regarding $\mathrm{Ca}$, there was not effect of the treatments.

The highest $\mathrm{N}$ content in the diagnostic leaf was achieved when the sorghum was 
Table 2 - Summary of joint analysis of variance (F values) to contents of nitrogen (N), phosphorus $(\mathrm{P})$, potassium $(\mathrm{K})$, calcium $(\mathrm{Ca})$ and magnesium $(\mathrm{Mg})$ in diagnostic leaf, and for plant height $(\mathrm{PH})$, stem diameter (SD), green mass productivity (GMP), dry mass productivity (DMP) and percentage of dry mass $(\% \mathrm{DM})$ of forage sorghum fertigated with $\mathrm{N}$ dosages in two harvests (summer and winter).

\begin{tabular}{|c|c|c|c|c|c|c|}
\hline \multirow[b]{2}{*}{ Sources of variation } & \multirow[b]{2}{*}{ GL } & \multicolumn{5}{|c|}{$\mathrm{F}$} \\
\hline & & $\mathrm{N}$ & $\mathrm{P}$ & $\mathrm{K}$ & $\mathrm{Ca}$ & $\mathrm{Mg}$ \\
\hline Blocks (Harvests) & 6 & $1.18^{\mathrm{ns}}$ & $1.38^{\mathrm{ns}}$ & $0.87^{\mathrm{ns}}$ & $1.44^{\mathrm{ns}}$ & $3.14^{\mathrm{ns}}$ \\
\hline Doses (D) & 3 & $7.68 * *$ & $7.67 * *$ & $10.16^{* *}$ & $0.29^{\mathrm{ns}}$ & $10.09 * *$ \\
\hline Harvests $(\mathrm{H})$ & 1 & $0.01^{\mathrm{ns}}$ & $1.82^{\mathrm{ns}}$ & $462.72 * *$ & $3.03^{\mathrm{ns}}$ & $713.73 * *$ \\
\hline $\mathrm{D} \times \mathrm{H}$ & 3 & $1.54^{\mathrm{ns}}$ & $3.74 *$ & $3.27 *$ & $0.22^{\mathrm{ns}}$ & $1.87^{\mathrm{ns}}$ \\
\hline CV $(\%)$ & & 6.35 & 8.39 & 10.58 & 15.19 & 7.14 \\
\hline Overall average $\left(\mathrm{g} \mathrm{kg}^{-1}\right)$ & & 25.32 & 3.67 & 21.27 & 3.61 & 7.21 \\
\hline Sources of variation & GL & $\mathrm{PH}$ & SD & GMP & DMP & $\% \mathrm{DM}$ \\
\hline Blocks (Harvests) & 6 & $2.17^{\mathrm{ns}}$ & $1.19^{\mathrm{ns}}$ & $1.71^{\mathrm{ns}}$ & $1.06^{\mathrm{ns}}$ & $0.33^{\mathrm{ns}}$ \\
\hline Doses (D) & 3 & $0.78^{\mathrm{ns}}$ & $1.39^{\mathrm{ns}}$ & $1.59^{\mathrm{ns}}$ & $1.41^{\mathrm{ns}}$ & $0.35^{\mathrm{ns}}$ \\
\hline Harvests $(\mathrm{H})$ & 1 & $2.18^{\mathrm{ns}}$ & $115.29 *$ & $5.52 *$ & $0.02^{\mathrm{ns}}$ & $26.23 * *$ \\
\hline $\mathrm{D} \times \mathrm{H}$ & 3 & $0.14^{\mathrm{ns}}$ & $1.93^{\mathrm{ns}}$ & $1.23^{\mathrm{ns}}$ & $1.82^{\mathrm{ns}}$ & $0.21^{\mathrm{ns}}$ \\
\hline CV (\%) & & 8.13 & 6.22 & 18.70 & 19.56 & 9.52 \\
\hline Overall average & & $283.39 \mathrm{~cm}$ & $15.34 \mathrm{~mm}$ & $46,449 \mathrm{~kg} \mathrm{ha}^{-1}$ & $17,386 \mathrm{~kg} \mathrm{ha}^{-1}$ & $37.80 \%$ \\
\hline
\end{tabular}

fertigated with $153.33 \mathrm{~kg} \mathrm{ha}^{-1}$ of $\mathrm{N}$, reaching the maximum estimated value of $26.69 \mathrm{~g} \mathrm{~kg}^{-1}$ (Figure 2A), and decreasing with greater doses. According to Malavolta et al. (1989), Cantarella et al. (1997) and Martinez et al. (1999), the N content would be in a suitable range among the following values, respectively: 13.0-15.0; 23.129.0 and $25.0-35.0$. It is observed, then, that the
$\mathrm{N}$ content in forage sorghum was considered satisfactory for crop development, even in the absence of $\mathrm{N}$ fertilization (23.2 $\mathrm{g} \mathrm{kg}^{-1}$ of $\mathrm{N}$ ), since the soil of the experimental area presented high values of organic matter in both harvests (Table 2).

The excess of $\mathrm{N}$ could caused a reduced absorption of $\mathrm{N}$ by the crop, due to a probable 


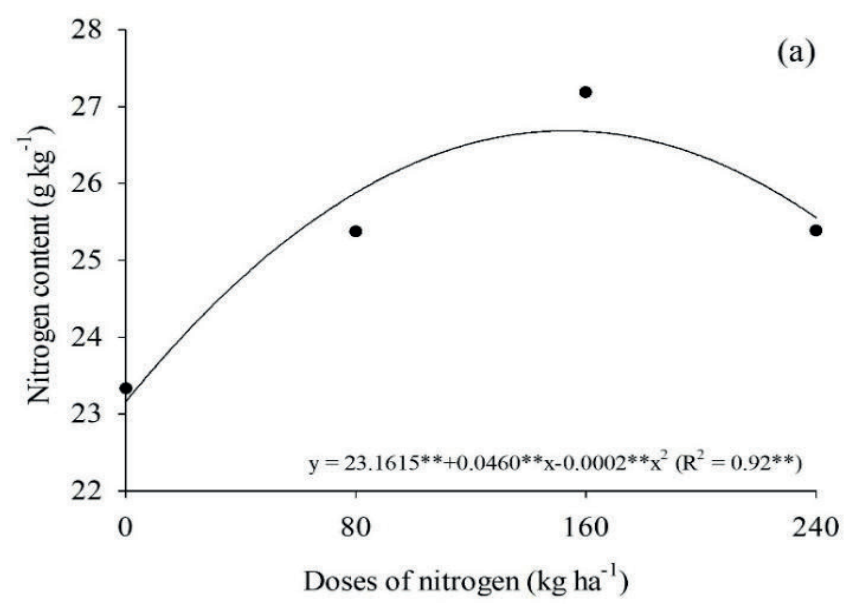

Figure 2 - Contents of nitrogen (a) and magnesium (b) in diagnostic leaf from variations in nitrogen doses of forage sorghum.

high volatilization of ammonia as a result of the high dose of urea in a soil with a $\mathrm{pH}$ value higher than 6.5 (Table 1), in addition to the high air temperatures verified during the experiment (Figure 1) (Ma et al., 2010; Tasca et al., 2011). This result emphasizes the necessity of adjustments in fertilization recommendations in order to provide an optimized quantity for sorghum, avoiding an excessive consumption of nutrients and an unnecessary waste of nitrogen fertilizer.

In relation to the $\mathrm{P}$ content, in summer, the values increased up to $4.07 \mathrm{~g} \mathrm{~kg}^{-1}$ for the dose of $118.33 \mathrm{~kg} \mathrm{ha}^{-1}$ of $\mathrm{N}$, falling for increased doses (Figure 3A). In the winter harvest, the dose of 240 $\mathrm{kg} \mathrm{ha}^{-1}$ of $\mathrm{N}$ promoted the maximum estimated value of $3.99 \mathrm{~g} \mathrm{~kg}^{-1}$ in the sorghum diagnostic leaf. In the Table 3, it is observed that the mean contents of $\mathrm{P}$ in the sorghum diagnostic leaf do not differentiate among harvests at a dose of 160

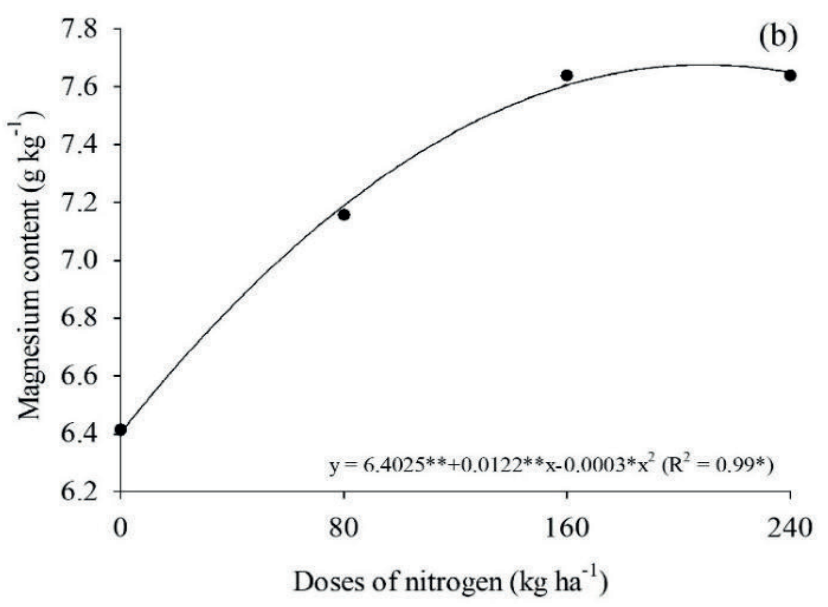

$\mathrm{kg} \mathrm{ha}^{-1}$ of $\mathrm{N}$. When sorghum was fertigated with $240 \mathrm{~kg} \mathrm{ha}^{-1}$ of $\mathrm{N}$ in winter cultivation, it had a mean content of $3.91 \mathrm{~g} \mathrm{~kg}^{-1}$ of $\mathrm{P}$, being superior to summer cultivation ( $3.16 \mathrm{~g} \mathrm{~kg}^{-1}$ of $\mathrm{P}$ ) for the same evaluated dose.

The $\mathrm{P}$ already available in the soil was sufficient for agricultural cultivation (Table 1), but the content of $\mathrm{P}$ in the diagnostic leaf increased when the $\mathrm{N}$ was applied (Figure 3A). This suggests that the absorption of $\mathrm{P}$ by sorghum plants until anthesis, accompanied the increase in induced growth due to a greater availability of $\mathrm{N}$ in soil (Serrão et al., 2012). It is important to emphasize that the $\mathrm{P}$ content in diagnostic leaf higher than $2 \mathrm{~g} \mathrm{~kg}^{-1}$ can be considered suitable for sorghum development (Cantarella et al., 1997), which was measured in all of the treatments.

For the content of $\mathrm{K}$, the diagnostic leaves of the winter harvest presented a linear increase with increasing doses of N (Figure 3B), reaching 

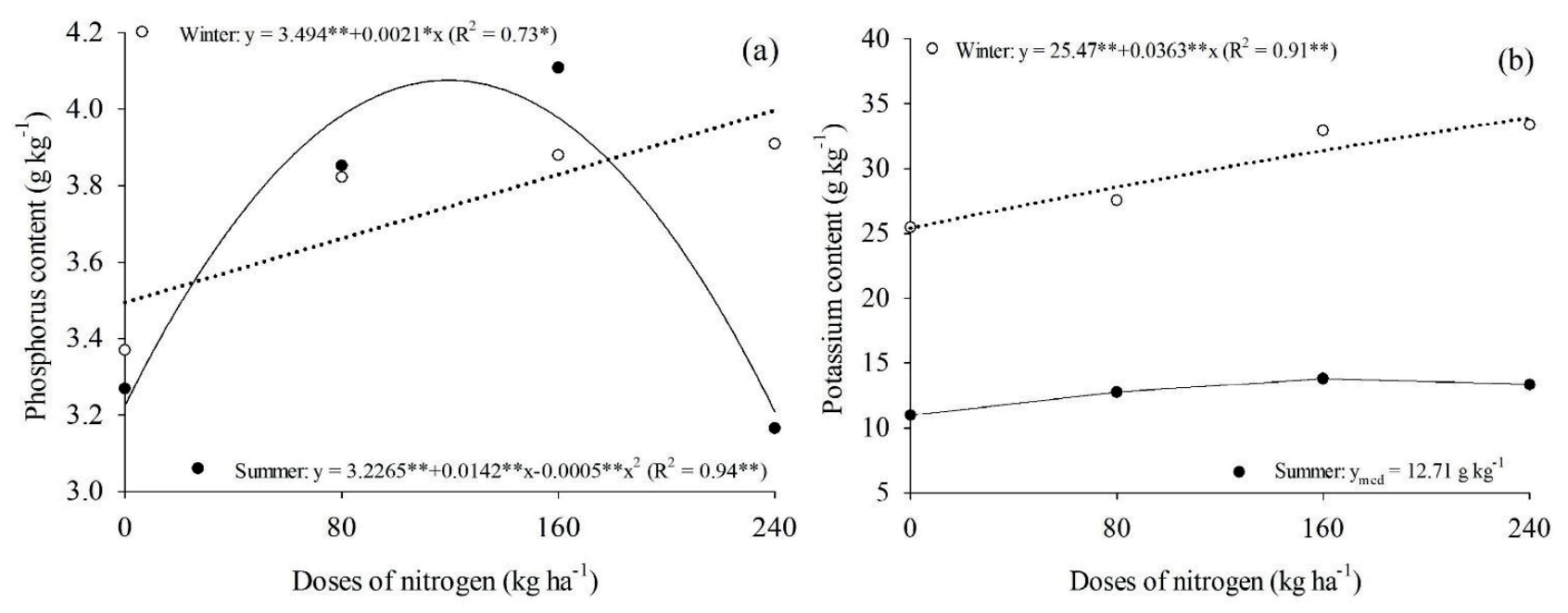

Figure 3 - Content of phosphorus (a) and potassium (b) in diagnostic leaf from variations in nitrogen doses and harvest seasons of forage sorghum.

a maximum estimated value of $34.18 \mathrm{~g} \mathrm{~kg}^{-1}$ for $240 \mathrm{~kg} \mathrm{ha}^{-1}$ of N. For summer harvest, there were no adjustments of the regressions, estimating an average content of $12.71 \mathrm{~g} \mathrm{~kg}^{-1}$ of $\mathrm{K}$. The values were closest to those suggested by Martinez et al. (1999) as a reference for leaf diagnosis of sorghum (13 to $30 \mathrm{~g} \mathrm{~kg}^{-1}$ of $\mathrm{K}$ ).

According to Table 3, it is gathered that for all of the doses of $\mathrm{N}$ evaluated, winter harvest provided the conditions for a higher absorption of $\mathrm{K}$ when compared to summer. This can be explained by the greater availability of the nutrient measured in the soil during the winter (Table 1), reducing the relation $(\mathrm{Ca}+\mathrm{Mg}) / \mathrm{K}$ and promoting vantages for the absorption of $\mathrm{K}$ in relation to $\mathrm{Mg}$ in the second harvest (Table 4). Galvão et al. (2015), evaluated the effects of increasing doses of $\mathrm{K}$ in forage sorghum crop, and an antagonistic effect was observed between $\mathrm{K}$ and $\mathrm{Mg}$ ions.
As for the content of $\mathrm{Mg}$, it was found that an increase in the dose of $\mathrm{N}$ applied, promoted significant increment in this variable, reaching a maximum value of content in diagnostic leaf (7.69 $\mathrm{g} \mathrm{kg}^{-1}$ ) with a dose of $210.34 \mathrm{~kg} \mathrm{ha}^{-1}$ of $\mathrm{N}$ (Figure 2B). The omission of $\mathrm{N}$, reduced the contents and accumulation of $\mathrm{Mg}$ in the shoot and in roots of the sorghum plants (Fonseca et al., 2008), while a large supply of $\mathrm{N}$ can promote greater absorption of Mg (Serrão et al., 2012).

The sorghum harvested during summer, obtained a superior mean content of $\mathrm{Mg}$ in the diagnostic leaf with $9.64 \mathrm{~g} \mathrm{~kg}^{-1}$, while in winter it was $4.78 \mathrm{~g} \mathrm{~kg}^{-1}$ (Table 4). The contents of $\mathrm{Mg}$ in both harvests can be considered high in relation to suitable content ranges proposed by Malavolta et al. (1989), Cantarella et al. (1997) and Martinez et al. (1999). These results may be due to low ratio of $\mathrm{Ca} / \mathrm{Mg}$ (1.61 in summer and 2.27 in winter), favoring absorption of $\mathrm{Mg}$ 
Table 3 - Average values of phosphorus and potassium contents in diagnostic leaf of the interaction of harvests and nitrogen doses fertigated in forage sorghum.

\begin{tabular}{ccccc}
\hline & \multicolumn{4}{c}{ Doses of nitrogen $\left(\mathrm{kg} \mathrm{ha}^{-1}\right)$} \\
\cline { 2 - 4 } Harvests & 0 & \multicolumn{4}{c}{160} & 240 \\
\cline { 2 - 4 } Summer & $3.27 \mathrm{a}^{1}$ & $3.82 \mathrm{a}$ & $3.88 \mathrm{a}$ & $3.16 \mathrm{~b}$ \\
Winter & $3.37 \mathrm{a}$ & $3.85 \mathrm{a}$ & $4.11 \mathrm{a}$ & $3.91 \mathrm{a}$ \\
\hline & \multicolumn{5}{c}{ Potassium $\left(\mathrm{g} \mathrm{kg}^{-1}\right)$} \\
\hline Summer & $10.98 \mathrm{~b}$ & $12.74 \mathrm{~b}$ & $13.79 \mathrm{~b}$ & $13.34 \mathrm{~b}$ \\
Winter & $25.46 \mathrm{a}$ & $27.55 \mathrm{a}$ & $32.95 \mathrm{a}$ & $33.36 \mathrm{a}$ \\
\hline
\end{tabular}

${ }^{1}$ Averages followed by the same letter in the column do not differ from each other by Tukey test, at $5 \%$ of probability.

in the detriment of $\mathrm{Ca}$, mainly in the first harvest (Salvador et al., 2011).

The average content of $\mathrm{Ca}$ verified in the experiments was $3.61 \mathrm{~g} \mathrm{~kg}^{-1}$ (Table 2), there was no influence of variations of the experiments. The soil of the experimental area presented high saturations of $\mathrm{Ca}$ in both seasons (Table 1). Even with a low relation of $\mathrm{Ca} / \mathrm{Mg}$, this did not damage the absorption of the nutrients by the plants and the average content was befitting with the default values for the diagnosis leaf (Cantarella et al., 1997; Martinez et al., 1999).

According to the joint analysis of the agronomic characteristics of forage sorghum (Table 2 ), there was an isolated effect of the harvests for diameter of stem, productivity of green mass and percentage of dry mass. In relation to plant height and dry mass productivity, a statistical difference between the treatments was not verified.

The average plant height observed in the experiments was $283.39 \mathrm{~cm}$ (Table 2). For the stem diameter, it was observed that planting sorghum in summer harvest presented a mean value of $17.16 \mathrm{~mm}$, higher than in winter (13.53 $\mathrm{mm}$ ) (Table 4). The productivity of green mass showed the same behavior, in other words, $50,056.79 \mathrm{~kg} \mathrm{ha}^{-1}$ in summer and 42,843.09 $\mathrm{tha}^{-1}$ in winter. On the other hand, the percentages of dry mass were $34.54 \%$ and $41.06 \%$ in summer and winter harvests, respectively, resulting in productivity of dry mass $\left(17,386.11 \mathrm{~kg} \mathrm{ha}^{-1}\right)$ being considered the same between the harvests and doses of $\mathrm{N}$ (Table 2). In this sense, the larger diameter of stem and dry mass productivity in summer are justified by the greater content of water in cellular tissues of sorghum plants.

In Barreiras, West of Bahia, Quadros et al. (2019) observed that the IPA467 reached, without water restrictions, a height of $286 \mathrm{~cm}, 19.20 \mathrm{~mm}$ of stem diameter, $30,700 \mathrm{~kg} \mathrm{ha}^{-1}$ of green mass, $12,600 \mathrm{~kg} \mathrm{ha}^{-1}$ of dry mass productivity and percentage of $41.04 \%$ of dry mass. In irrigated 
Table 4 - Average values of magnesium content in diagnostic leaf, stem diameter, green mass productivity and percentage of dry mass of forage sorghum cultivated during two harvests (summer and winter).

\begin{tabular}{ccccc}
\hline Harvests & $\begin{array}{c}\text { Magnesium } \\
\left(\mathrm{g} \mathrm{kg}^{-1}\right)\end{array}$ & $\begin{array}{c}\text { Stem diameter } \\
(\mathrm{mm})\end{array}$ & $\begin{array}{c}\text { Green mass productivity } \\
\left(\mathrm{kg} \mathrm{ha}^{-1}\right)\end{array}$ & $\begin{array}{c}\text { Percentage of dry mass } \\
(\%)\end{array}$ \\
\hline Summer & $9.64 \mathrm{a}^{1}$ & $17.16 \mathrm{a}$ & $50,056.79 \mathrm{a}$ & $34.54 \mathrm{~b}$ \\
Winter & $4.78 \mathrm{~b}$ & $13.53 \mathrm{~b}$ & $42,843.09 \mathrm{~b}$ & $41.06 \mathrm{a}$ \\
\hline
\end{tabular}

${ }^{1}$ Averages followed by the same letter in the column do not differ from each other by Tukey test, at $5 \%$ of probability.

cultivation forage/sweet sorghum (water depthsof $306 \mathrm{~mm}$ ) in the municipality of Mossoró-RN, Brazilian semiarid, Costa et al. (2019) obtained a maximum productivity of green mass of $57,000 \mathrm{~kg} \mathrm{ha}^{-1}$ (cultivar Ponta Negra) and 43.300 $\mathrm{kg} \mathrm{ha}^{-1}$ (BRS 506). In Leme do Prado, Minas Gerais, Albuquerque et al. (2013) evaluated the agronomic characteristics of seven genotypes of forage sorghum and reached means of $240 \mathrm{~cm}$ in height, $11.46 \mathrm{~mm}$ stem diameter and 17,330 kg ha $^{-1}$ of dry mass yield.

Based on the results of macronutrients content of diagnostic leaf and the agronomic characteristics of forage sorghum fertigated with $\mathrm{N}$ doses, it can be inferred that, in both harvests, the contents of $\mathrm{N}, \mathrm{P}, \mathrm{K}, \mathrm{Ca}$ and $\mathrm{Mg}$ may be considered sufficient for full development of the crop in the present study, since the accumulation of photoassimilates in dry mass of the sorghum was similar in both harvests and either equal or greater when compared to the literature.

\section{Conclusions}

The contents of macronutrients in diagnostic leaf of forage sorghum are increased with increasing doses of $\mathrm{N}$ by fertigation, except Ca which was not influenced.

The winter harvest presented a higher content of $\mathrm{K}$ in the diagnostic leaf of sorghum, while the summer harvest was more beneficial for $\mathrm{Mg}$ absorption.

The doses of $\mathrm{N}$ and the harvests do not influence the dry mass yield of sorghum IPA 467.

The contents of $\mathrm{N}\left(23.16-26.69 \mathrm{~g} \mathrm{~kg}^{-1}\right)$, $\mathrm{P}$ (3.16-4.11 $\left.\mathrm{g} \mathrm{kg}^{-1}\right), \mathrm{K}\left(10.98-33.36 \mathrm{~g} \mathrm{~kg}^{-1}\right), \mathrm{Ca}$ (3.61 $\mathrm{g} \mathrm{kg}^{-1}$ ) and $\mathrm{Mg}\left(4.78-9.64 \mathrm{~g} \mathrm{~kg}^{-1}\right)$ can be considered sufficient for full development of the crop in the conditions of the present study.

\section{Acknowledgements}

Special thanks are due to the Coordenação de Aperfeiçoamento de Pessoal de Nível Superior (CAPES) by the grant of doctoral scholarship and to the Instituto Federal de Alagoas 
(IFAL), Campus Piranhas, for the availability of laboratory infrastructure.

\section{References}

ALBUQUERQUE, C. J. B.; JARDIM, R. R.; ALVES, D. D.; GUIMARÃES, A. S.; PORTO, E. M. V. Características agronômicas e bromatológicas dos componentes vegetativos de genótipos de sorgo forrageiro em Minas Gerais. Revista Brasileira de Milho e Sorgo, v. 12 , n. 2, p. 164-182, 2013. DOI: https://doi. org/10.18512/1980-6477/rbms.v12n2p164-182

BUSO, W. H. D.; MORGADO, H. S.; SILVA, L. B.; FRANÇA, A. F. S. Utilização do sorgo forrageiro na alimentação animal. Publicações em Medicina Veterinária e Zootecnia, v. 5, n. 23, p. 1145, 2011.

CANTARELLA, H.; RAIJ, B. van.; CAMARGO, C. E. O. Cereais. In: RAIJ, B. van.; CANTARELlA, H.; QUAGGIO, J. A.; FURLANI, A. M. C. (Eds). Recomendações de adubação e calagem para o Estado de São Paulo. 2. ed. rev. Campinas: IAC, 1997. p. 45-47 (Boletim Técnico, 100).

COELHO, D. S.; SIMÕES, W. L.; SALVIANO, A. M.; MESQUITA, A. C.; ALBERTO, K. C. Gas exchange and organic solutes in forage sorghum genotypes grown under different salinity levels. Revista Brasileira de Engenharia Agrícola e Ambiental, v. 22, n. 4, p. 231-236, 2018. DOI: https://doi.org/10.1590/1807-1929/agriambi. v22n4p231-236

COSTA, A. R. F. C.; COSTA, J. P. N.; MEDEIROS, J. F.; SILVA, M. V. T.; LINO, V. A. S. Desempenho de variedades de sorgo dupla aptidão submetidas a diferentes lâminas de irrigação com água salina. Revista Brasileira de Milho e Sorgo, v. 18, n. 3, p. 417-428, 2019. DOI: https://doi.org/10.18512/1980-6477/rbms. v18n3p417-428

ELIAS, O. F. A. S.; LEITE, M. L. M. V.; AZEVEDO, J. M.; SILVA, J. P. S. S. S.; NASCIMENTO, G. F.; SIMPLÍCIO, J. B. Características agronômicas de cultivares de sorgo em sistema de plantio direto no semiárido de Pernambuco. Ciência Agrícola, v. 14, n. 1, p. 29-36, 2016. DOI: http://dx.doi.org/10.28998/ rca.v14i1.2318

FERREIRA, D. F. Sisvar: a computer statistical analysis system. Ciência e Agrotecnologia, Lavras, v. 35, n. 6, p. 1039-1042, nov./dez. 2011. DOI: https://doi.org/10.1590/S141370542011000600001

FONSECA, I. M.; PRADO, R. M.; ALVES, A. U.; GONDIM, A. R. O. Crescimento e nutrição do sorgo (cv. BRS 304) em solução nutritiva. Revista de Biologia e Ciências da Terra, v. 8, n. 2, p. 113-124, 2008.

GALVÃO, J. R.; FERNANDES, A. R.; SIVA, V. 
F. A.; PINHEIRO, D. P.; MELO, N. C. Adubação potássica em híbridos de sorgo forrageiro cultivados em sistemas de manejo do solo na Amazônia oriental. Revista Caatinga, v. 28, n. 4, p. 70-79, 2015. DOI: https://doi.org/10.1590/198321252015v28n408rc

MA, B. L.; WU, T. Y.; TREMBLAY, N.; DEEN, W.; MCLAUGHLIN, N. B; MORRISON , M. J.; STEWART, G. On-farm assessment of the amount and timing of nitrogen fertilizer on ammonia volatilization. Agronomy Journal, v. 102, n. 1, p. 134-144, 2010. DOI: https://doi.org/10.2134/ agronj2009.0021

MACEDO, C. H. O.; SANTOS, E. M.; SILVA, T. C.; ANDRADE, A. P.; SILVA, D. S.; SILVA, A. P. G.; OLIVEIRA, J. S. Produção e composição bromatológica do sorgo (Sorghum bicolor) cultivado sob doses de nitrogênio. Archivos de Zootecnia, v. 61, n. 234, p. 209-216. 2012. DOI: http://dx.doi.org/10.4321/S000405922012000200005

MALAVOLTA, E.; VITTI, G. C.; OLIVEIRA, S. A. Avaliação do estado nutricional das plantas: princípios e aplicações. Piracicaba: POTAFOS, 1989. $201 \mathrm{p}$.

MARTINEZ, H. E. P.; CARVALHO, J. G.; SOUZA, R. B. Diagnose foliar. In: RIBEIRO, A. C.; GUIMARÃES, P. T. G.; AlvAREZ, V. V. H. (Eds.). Recomendação para uso de corretivos e fertilizantes em Minas Gerais: $5^{\mathrm{a}}$ Aproximação.
Viçosa: CFSMG, 1999. p.143-168.

NIRMAL, S. S.; SOLANKE,A. V.; DUDHADE, D. D.; SHINDE, M. S.; GADAKH, S. R.; DURGUDE,A. G; DAMAME, S. V. Response of forage sorghum [Sorghum bicolor (1). Moench] cultivars to nitrogen levels. International Journal of Science, Environment and Technology, v. 5, n. 4, p. 2605-2609, 2016.

QUADROS, D. G.; TELES, E. B. S.; SANTOS, L. H. B.; ANDRADE, A. P. Características agronômicas e rendimento forrageiro de genótipos comerciais de sorgo forrageiro na região oeste da Bahia. Revista Agrária Acadêmica, v. 2, n. 2, p. 45-59, 2019. DOI: http://dx.doi.org/10.32406/v2n22019/45-59/ agrariacad

SALVADOR, J. T.; CARVALHO, T. C.; LUCCHESI, L. A. C. Relações cálcio e magnésio presentes no solo e teores foliares de macronutrientes. Revista Acadêmica: Ciência Agrária e Ambiental, v. 9, n. 1, p. 27-32, 2011. DOI: http://dx.doi.org/10.18512/1980-6477/ rbms.v12n2p164-182

SANTOS, F. C.; COELHO, A. M.; RESENDE, A. V.; MIRANDA, R. A. Correção do solo e adubação na cultura do sorgo. Informe Agropecuário, v. 35, n. 278, p. 76-88, 2014.

SERRÃO, M. G.; MENINO, M. R.; MARTINS, J. C.; CASTANHEIRA, N.; LOURENÇO, 
M. E.; JANUÁRIO, I.; FERNANDES, M. L.; GONÇALVES, M. C. Mineral leaf composition of sweet sorghum in relation to biomass and sugar yields under diferente nitrogen and salinity conditions. Communications in Soil Science and Plant Analysis, v. 43, n. 18, p. 2376-2388, 2012. DOI: http://dx.doi.org/10.1080/00103624. 2012.708076

SILVA, D. J.; LEITE, J. P.; SILVA, M. C. L. Avaliação da fertilidade do solo. CAVALCANTI, F. J. A. (Coord). Recomendações de adubação para o Estado de Pernambuco. 3. ed. rev. Recife: Instituto Agronômico de Pernambuco, - IPA, 2008. p. 63.

SILVA, F. C. (Ed.). Manual de análises químicas de solos, plantas e fertilizantes. 2. ed. rev. ampl. Brasília: Embrapa Informação Tecnológica, 2009. 627 p.

SOUSA, I. F.; SILVA, V. P. R.; SABINO, F. G.; NETTO, A. O. A.; SILVA, B. K. N.; AZEVEDO, P. V. Evapotranspiração de referência nos perímetros irrigados do Estado de Sergipe. Revista Brasileira de Engenharia Agrícola e Ambiental, v. 14, n. 6, p. 633-644, 2010. DOI: https://doi.org/10.1590/S141543662010000600010
SOUZA, E. G. F.; CRUZ, E. A.; SILVA, M. O.; PRATES, F. B. S.; BARROS JÚNIOR, A. P.; BEZERRA NETO, F. Profitability of maize for silage fertigated with nitrogen doses in different crops in a semiarid region of Brazil. Acta Scientiarum. Agronomy, v. 42, e42458, 2020. DOI: http://dx.doi.org/10.4025/actasciagron. v42i1.42458

TASCA, F. A.; ERNANI, P. R.; ROGERI, D. A; GATIBONI, L. C.; CASSOL, P. C. Volatilização de amônia do solo após a aplicação de ureia convencional ou com inibido de uréase. Revista Brasileira de Ciência do Solo, v. 35, n. 2, p. 493-502, 2011. DOI: https://doi.org/10.1590/ S0100-06832011000200018

TEDESCO, M. J.; GIANELLO, C.; BISSANI, C. A.; BOHNEN, H.; WOLKWEISS, S. J. Análises de solo, plantas e outros materiais. Porto Alegre: Departamento de Solos Universidade Federal do Rio Grande do Sul, 1995. 174 p. (Boletim Técnico, 5). 